\title{
STRATEGI PENINGKATAN DAN ALOKASI PENERIMAAN NEGARA BUKAN PAJAK UNTUK PENINGKATAN OPERASIONAL LAYANAN PELABUHAN PERIKANAN
}

\author{
Siti Hajar Suryawati, Yayan Hikmayani dan Agus Heri Purnomo' \\ ${ }^{1}$ Peneliti pada Balai Besar Riset Sosial Ekonomi Kelautan dan Perikanan \\ JI. KS Tubun Petamburan VI Jakarta 10260. \\ Telp. (021)53650162, Fax. (021)53650159 \\ Diterima 23 Maret 2010 - Disetujui 26 Juni 2010
}

\begin{abstract}
ABSTRAK
Penelitian ini merupakan analisa tentang upaya meningkatkan penerimaan Negara bukan pajak (PNBP) pelabuhan perikanan yang dilakukan pada bulan Juni-Agustus 2009. Penelitian dilakukan dengan pendekatan studi kasus, yang didasarkan pada hasil pengamatan dan analisis pada pelabuhan perikanan sampel yaitu Pelabuhan Perikanan Samudera (PPS). Pelabuhan Perikanan Nusantara (PPN) dan Pelabuhan Perikanan pantai (PPP). Data yang dikumpulkan terdiri dari data primer dan sekunder. Analisis data menggunakan metode SWOT (at). Hasil penelitian ini menghasilkan identifikasi strategi peningkatan layanan melalui optimal strength, Weakness, Opportunity, There sasi PNBP pelabuhan perikanan. Dari hasil analisis, teridentifikasi beberapa strategi kunci untuk peningkatan PNBP yaitu: (a) memaksimalkan kualitas layanan jasa dengan sarana prasarana yang ada; (b) perbaikan dan penambahan sarana-prasarana pelabuhan; (c) peningkatan kapasitas sumberdaya manusia; (d) meningkatkan kerjasama dengan institusi terkait; dan (e) peningkatan pengawasan serta perbaikan aturan serta implementasinya. Implikasi dari hasil kajian ini adalah perlunya kebijakan pengalokasian dana PNBP yang memberikan prioritas pada hal-hal yang tercakup dalam daftar strategi kunci tersebut.
\end{abstract}

Kata Kunci: optimalisasi, penerimaan negara bukan pajak, pelabuhan perikanan, SWOT

\section{Abstract: Strategy to Increase and to Optimize Allocation of Non-Tax State Revenues for Better Services of Fishing Ports, by Siti Hajar Suryawati, Yayan Hikmayani and Agus Heri Purnomo}

This research is analysis on strategy to increase and optimize allocation of non-tax state revenue $(P N B P)$. It uses a case-study approach combining with observation on selected fishing ports according to their classification: Oceanic Fishing Port (PPS), Inter-island Fishing Port (PPN), and Fish Landing Place (PPI). This research collects primary and secondary data while analytical method use a 'SWOT'. Results show that four strategies to increase and optimize allocation of non-tax state revenue were identified, namely: (a) maximizing the quality of services using the existing facilities and infrastructure; (b) improving and adding the port facilities and infrastructure; (c) improving the capacity of human resources; (d) enhanching collaboration among related institution; and (e) improving surveillance and improving the regulations and their implementation. It then recommends allocation policy of PNBP by prioritizing services.

Keyword: optimization, non-tax state revenue, fishing port, SWOT 


\section{PENDAHULUAN}

Pelabuhan perikanan mempunyai fungsi pemerintahan dan pengusahaan guna mendukung kegiatan yang berhubungan dengan pengelolaan dan pemanfaatan sumber daya ikan dan lingkungannya mulai dari pra-produksi, produksi, pengolahan sampai dengan pemasaran. Dalam menunjang peningkatan produksi di sektor penangkapan ikan, tersedianya prasarana pelabuhan perikanan mempunyai arti yang sangat penting, karena sebagai sebuah infrastruktur pembangunan ekonomi, pelabuhan perikanan memiliki peran penting sebagai penggerak roda perekonomian di suatu kawasan. Dalam UU No 45 Tahun 2009 tentang Perubahan atas Undang-Undang No 31 Tahun 2004 tentang Perikanan disebutkan bahwa Pelabuhan Perikanan adalah tempat yang terdiri atas daratan dan perairan di sekitarnya dengan batas-batas tertentu sebagai tempat kegiatan pemerintahan dan kegiatan sistem bisnis perikanan yang digunakan sebagai tempat kapal perikanan bersandar, berlabuh, dan/atau bongkar muat ikan yang dilengkapi dengan fasilitas keselamatan pelayaran dan kegiatan penunjang perikanan.

Berbagai pengeluaran diperlukan untuk meningkatkan layanan pelabuhan diantaranya berupa: (i) perencanaan, pengembangan, pemeliharaan serta pemanfaatan sarana pelabuhan perikanan; (ii) pelayanan teknis kapal perikanan dan kesyahbandaran perikanan; (iii) koordinasi pelaksanaan urusan keamanan, ketertiban dan pelaksanaan kebersihan kawasan pelabuhan perikanan; (iv) pengembangan dan fasilitasi pemberdayaan masyarakat perikanan; (v) pelaksanaan fasilitasi dan koordinasi di wilayahnya untuk peningkatan produksi, distribusi dan pemasaran hasil perikanan; (vi) pelaksanaan pengumpulan, pengolahan dan penyajian data dan statistik perikanan; (vii) pengembangan dan pengelolaan sistem informasi dan publikasi hasil riset, produksi dan pemasaran hasil perikanan tangkap di wilayahnya.

Sejauh ini, dukungan pendanaan tersebut diperoleh melalui mekanisme Anggaran Pendapatan dan Belanja Negara (APBN) dan PNBP. PNBP dan kualitas jasa layanan merupakan dua hal yang saling memperkuat satu dengan lainnya. Apabila PNBP meningkat, maka sarana prasarana maupun jenis dan kualitas layanan dapat ditingkatkan, begitu pula sebaliknya. Dengan demikian, upaya-upaya untuk meningkatkan PNBP pelabuhan secara konsisten sangat relevan dengan upaya peningkatan layanan pelabuhan dari waktu ke waktu. Jasa pelayanan di pelabuhan perikanan ini merupakan salah satu potensi PNBP di sektor kelautan dan perikanan yang disetorkan kembali ke negara selain jasa pungutan perikanan, jasa pengembangan dan pengujian mutu hasil perikanan, jasa penangkapan ikan, jasa budidaya perikanan, jasa karantina ikan, jasa pendidikan dan pelatihan dan jasa penyewaan fasilitas.

PNBP dapat dimanfaatkan untuk membiayai kembali pelaksanaan operasional jasa pelayanan yang dilakukan oleh pelabuhan perikanan. Namun dalam pelaksanaannya potensi PNBP sektor kelautan dan perikanan ini tidak sepenuhnya masuk ke rekening Kementerian Kelautan dan Perikanan (KKP). Hal ini disebabkan karena potensi tersebut ditarik oleh Pemerintah Daerah atau Perusahaan Umum Prasarana Perikanan Samudra (Perum PPS).

Berdasarkan latar belakang tersebut maka tujuan dari penulisan ini adalah untuk mengidentifikasi strategi peningkatan layanan melalui optimalisasi PNBP pelabuhan perikanan, dengan fokus penelitian pada pemahaman fungsi pelabuhan, fasilitas pelabuhan, pelayanan jasa pelabuhan, sampai pada strategi peningkatan PNBP. 


\section{METODOLOGI}

\section{Kerangka Pendekatan dan Ruang Lingkup}

PNBP di sektor kelautan dan perikanan, sesuai Peraturan Pemerintah Nomor 19 Tahun 2008 tentang Tarif atas Jenis PNBP yang berlaku pada KKP, digunakan sebagai salah satu sumber pembiayaan pembangunan kelautan perikanan. PNBP KKP dialokasikan ke seluruh kabupaten/kota dengan porsi $80 \%$ dan 20\% digunakan untuk Pemerintah Pusat sesuai Undang-Undang Nomor 33 Tahun 2004 tentang Perimbangan Keuangan Antara Pusat dan Daerah. Jenis penerimaan yang dibagikan tersebut merupakan jenis penerimaan sumber daya alam (SDA) perikanan, adapun jenis penerimaan lain berupa penerimaan non SDA digunakan untuk imbal jasa bagi unit kerja yang menghasilkan PNBP dengan persentase secara proporsional berdasarkan Keputusan Menteri Keuangan Nomor 556/KMK.08/2003.

Dalam pelaksanaannya timbul permasalahan karena realisasi penerimaan PNBP tidak sesuai target. Sampai dengan akhir tahun 2008 hanya mencapai Rp. 104,19 miliar atau 48,18 persen dari target sebesar Rp. 215,78 miliar. Untuk meningkatkan upaya pencapaian penerimaan PNBP KKP tersebut maka dilakukan analisis SWOT terhadap berbagai faktor baik eksternal maupun internal yang diduga berpengaruh terhadap pelaksanaan pemungutannya. Selanjutnya berdasarkan hasil analisis dapat diketahui strategi peningkatan optimalisasi PNBP KKP. Kerangka pendekatan studi ini dapat dilihat pada Gambar 1.

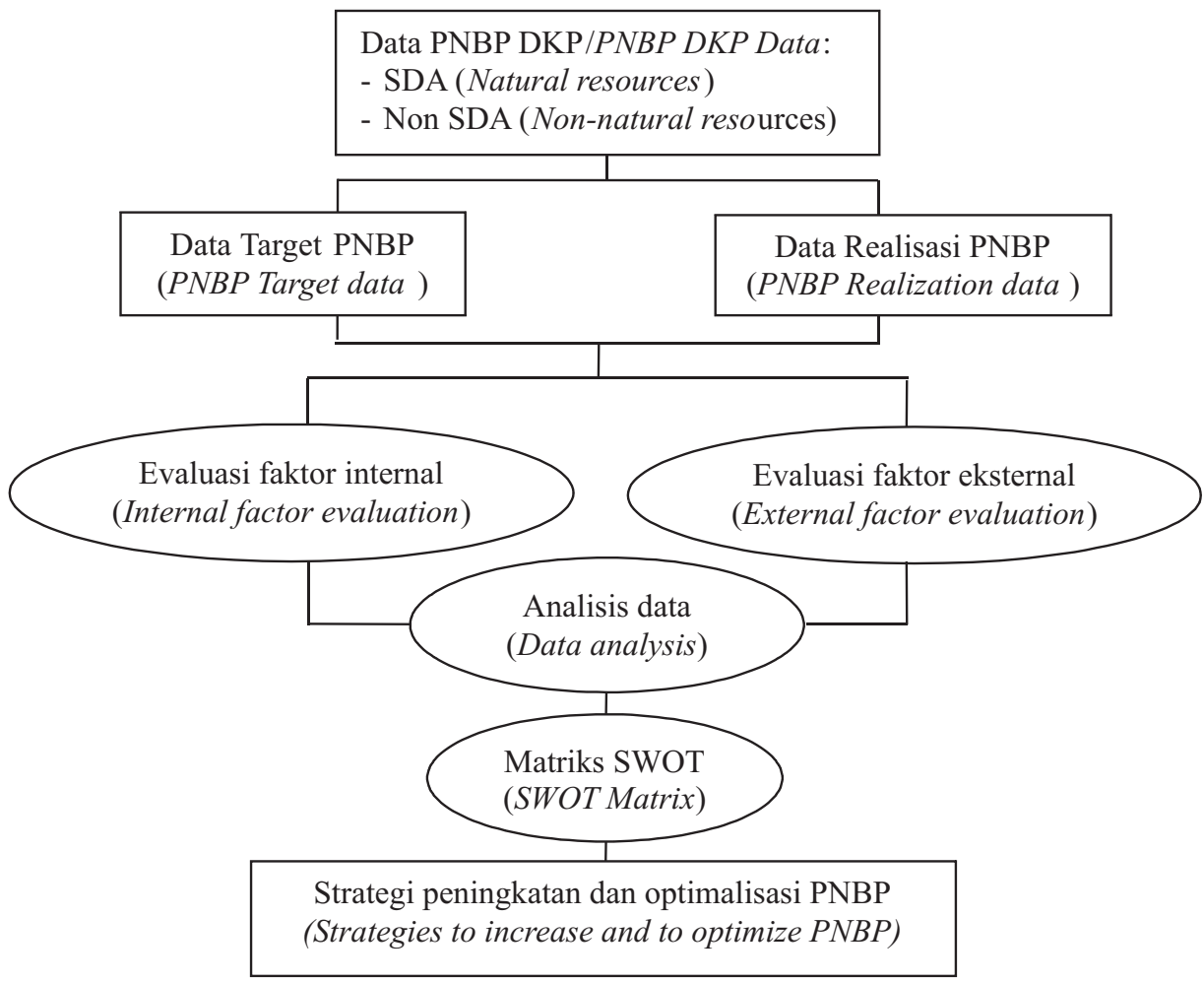

Gambar 1. Skema Kerangka Pendekatan dan Ruang Lingkup Studi Figure 1. Scematic Framework Approach and Scope of the Study 


\section{Lokasi dan Waktu Penelitian}

Penelitian ini dilaksanakan berdasarkan pendekatan studi kasus. dimana strategistrategi optimalisasi PNBP dirumuskan berdasarkan analisis terhadap pelabuhan. Penelitian ini dilaksanakan pada bulan Juni Agustus 2009. Pelabuhan perikanan yang dipilih untuk mewakili tiga (3) kelas layanannya, sebagai lokasi kasus acuan. Ketiga kelas tersebut adalah Pelabuhan Perikanan Samudera (PPS), Pelabuhan Perikanan Nusantara (PPN) dan Pelabuhan Perikanan Pantai (PPP). Kelas keempat, yaitu Pelabuhan Pendaratan Ikan (PPI) tidak dijadikan sampel dengan pertimbangan keterbatasan jangkauan wilayah penelitian. Adapun lokasi pelabuhan yang dijadikan sampel yaitu: PPS Nizam Zachman Jakarta (Provinsi DKI Jakarta), PPS Cilacap (Provinsi Jawa Tengah), PPN Pelabuhan Ratu (Provinsi Jawa Barat), PPN Ambon (Provinsi Ambon), PPN Pemangkat (Provinsi Kalimantan Barat) dan PPP Karangantu Serang (Provinsi Banten).

\section{Jenis dan Sumber Data}

Data yang dikumpulkan adalah data primer dan data sekunder yang bersifat kuantitatif dan kualitatif, yang mencakup empat (4) aspek utama, yaitu: kekuatan, kelemahan, tantangan dan hambatan dalam optimalisasi penerimaan PNBP. Data primer dikumpulkan melalui wawancara dengan responden dan nara sumber yang terpilih yang memiliki pengaruh dalam pengelolaan pelabuhan perikanan dengan cara FGD (Focus Group Discussion). Narasumber yang dimaksud adalah: Kepala Seksi PNBP KKP, Kepala Pelabuhan, Kepala Bidang Tata Usaha, Bendahara Penerima dan Pengeluaran, Kepala Dinas Kelautan dan Perikanan, Syahbandar, Kepala Tempat Pelelangan Ikan (TPI), Koperasi dan staf pelaksana di lapangan termasuk nelayan. Data sekunder yang dikumpulkan berupa laporan tahunan pada pelabuhan perikanan di setiap lokasi penelitian serta data dan informasi dari berbagai instansi lainnya.

\section{Metode Pengumpulan Data}

Pengumpulan data dilakukan dengan pendekatan survei, diskusi dan pengamatan lapang.

\section{Metode Analisis Data}

Analisis data dilakukan melalui dua tahap. Pada tahap pertama, data yang diperoleh diolah secara deskriptif (Nasir, 1983). Pada tahap kedua, hasil analisis deskriptif tersebut dipergunakan untuk melakukan analisis SWOT. Analisis SWOT adalah analisis kualitatif yang digunakan untuk mengidentifikasi berbagai faktor secara sistematis untuk memformulasikan strategi suatu kegiatan. SWOT adalah singkatan dari Strength, Weakness, Opportunities dan Threats (Rangkuti, 2000). Analisis SWOT ini mencakup dua komponen utama, yaitu faktor internal dan eksternal. Faktor eksternal adalah yang berkaitan dengan lingkungan tugas dan lingkungan sosial sedangkan faktor internal meliputi bidang-bidang fungsional, sumberdaya dan budaya kerja dalam organisasi (Wheelen dan Hunger, 2000).

Secara konseptual analisis faktor-faktor eksternal dan internal mencakup kegiatankegiatan sebagai berikut:

i. mengidentifikasi faktor-faktor eksternal yang secara strategis merupakan peluang dan ancaman terhadap pelaksanaan pembangunan wilayah pesisir;

ii. mengidentifikasi faktor-faktor kunci internal yang merupakan kekuatan dan kelemahan yang dihadapi dalam pembangunan wilayah pesisir;

iii. mengumpulkan data dan informasi mengenai faktor-faktor tersebut; dan

iv. apabila dianggap perlu, membuat proyeksi mengenai perkembangan faktor-faktor tersebut selama periode perencanaan.

\section{HASIL DAN PEMBAHASAN}

\section{Sumber PNBP dari Layanan Jasa Pelabuhan \\ Jenis jasa pelayanan pelabuhan yang} diberikan oleh pengelola pelabuhan perikanan berimplikasi pada besaran PNBP yang 
diterima oleh Pelabuhan Perikanan. Berdasarkan UU No. 20 Tahun 1997 tentang Penerimaan Negara Bukan Pajak disebutkan bahwa pengertian PNBP adalah seluruh penerimaan pemerintah pusat yang tidak berasal dari penerimaan perpajakan. PNBP dapat dikelompokkan meliputi: (a) penerimaan yang bersumber dari pengelolaan dana pemerintah; (b) penerimaan dari pemanfaatan sumber daya alam; (c) penerimaan dari hasilhasil pengelolaan kekayaan negara yang dipisahkan; (d) penerimaan dari kegiatan pelayanan yang dilaksanakan pemerintah; (e) penerimaan berdasarkan putusan pengadilan dan yang berasal dari pengenaan denda administrasi; (f) penerimaan berupa hibah yang merupakan hak pemerintah; dan (g) penerimaan lainnya yang diatur dalam Undang-Undang tersendiri. Jenis PNBP yang diberlakukan pada pelabuhan perikanan mengacu pada jenis PNBP yang ditetapkan Direktorat Jenderal Perikanan Tangkap (Tabel 1).

Tabel 1. Jenis-Jenis PNBP di Lingkup Direktorat Jenderal Perikanan Tangkap, 2008 Table 1. Various Types of 'PNBP' in the General Directorate of Capture Fisheries, 2008

\begin{tabular}{|c|c|c|c|c|}
\hline $\begin{array}{l}\text { Nol } \\
\text { No }\end{array}$ & $\begin{array}{l}\text { Sumberl } \\
\text { Sources }\end{array}$ & $\begin{array}{l}\text { Kelompok } \\
\text { Penerimaan } \\
\text { (Revenue } \\
\text { group) }\end{array}$ & $\begin{array}{l}\text { Jenis Penerimaan } \\
\text { (Revenue Kinds) }\end{array}$ & $\begin{array}{c}\text { Rincian/ } \\
\text { Description }\end{array}$ \\
\hline 1 & $\begin{array}{l}\text { Pusat/ } \\
\text { Central } \\
\text { institution }\end{array}$ & $\begin{array}{l}\text { Penerimaan } \\
\text { sumberdaya } \\
\text { alam } \\
\text { Revenue from } \\
\text { natural resources }\end{array}$ & $\begin{array}{l}\text { - Pendapatan } \\
\text { Perikanan/ } \\
\text { Fisheries } \\
\text { revenue }\end{array}$ & $\begin{array}{l}\text { - Pungutan Pengusahaan Perikanan } \\
\text { (PPP) /Fisheries business fee } \\
\text { - Pungutan Hasil Perikanan (PHP) } \\
\text { /Fisheries product tax }\end{array}$ \\
\hline \multirow[t]{5}{*}{2} & \multirow[t]{5}{*}{$\begin{array}{l}\text { UPT/ } \\
\text { Branch }\end{array}$} & \multirow[t]{3}{*}{$\begin{array}{l}\text { Penerimaan } \\
\text { umum/General } \\
\text { revenue }\end{array}$} & $\begin{array}{l}\text { - Sewa rumah } \\
\text { dinas/negeri/ } \\
\text { Housing rental } \\
\text { - Sewa gedung, } \\
\text { gudang, bangunan/ } \\
\text { Facility rental }\end{array}$ & $\begin{array}{l}\text { - Rumah /Houses } \\
\text { - Mess /Dormitory } \\
\text { - Ruang pertemuan/aula /Meeeting } \\
\text { room } \\
\text { - Gudang/bangunan permanen/semi } \\
\text { permanen /Wharehouse } \\
\text { - Kantin/kios/koperasi } \\
\text { (cafetaria/kiosks/cooperatives) } \\
\text { - Gedung kantor/ Office building } \\
\text { - Bangunan beratap lainnya /Other } \\
\text { roofed building }\end{array}$ \\
\hline & & & $\begin{array}{l}\text { - Sewa benda } \\
\text { bergerak /Mobile } \\
\text { asset rental }\end{array}$ & $\begin{array}{l}\text { - Crane truck } \\
\text { - Dump Truck, pick up, bus, etc } \\
\text { - Forklift } \\
\text { - Back Hoe } \\
\text { - Kapal Motor /Engined boat, Tug } \\
\text { Boat, etc }\end{array}$ \\
\hline & & & $\begin{array}{l}\text { - Sewa benda tidak } \\
\text { bergerak /non- } \\
\text { mobile asset }\end{array}$ & - Tanah lahan /Land property \\
\hline & & Penerimaan & rental & Perbaikan kapal, bengkel atau \\
\hline & & $\begin{array}{l}\text { Fungsional/ } \\
\text { Functional } \\
\text { revenue }\end{array}$ & $\begin{array}{l}\text { - Jasa tenaga } \\
\text { /pekerjaan/Labor } \\
\text { work services) }\end{array}$ & $\begin{array}{l}\text { - peralatannya/ Boat or other } \\
\text { equipment repairs } \\
\text { - Slip way } \\
\text { - Docking } \\
\text { - Pengerukan /Dredging } \\
\text { Pas masuk / Entrance fee }\end{array}$ \\
\hline
\end{tabular}




\section{Lanjutan Tabel 1/Continues Table 1}

\begin{tabular}{|c|c|c|c|c|}
\hline $\begin{array}{l}\text { Nol } \\
\text { No }\end{array}$ & $\begin{array}{l}\text { Sumberl } \\
\text { Sources }\end{array}$ & $\begin{array}{l}\text { Kelompok } \\
\text { Penerimaan } \\
\text { (Revenue } \\
\text { group) }\end{array}$ & $\begin{array}{c}\text { Jenis Penerimaan } \\
\text { (Revenue Kinds) }\end{array}$ & $\begin{array}{c}\text { Rincian/ } \\
\text { Description }\end{array}$ \\
\hline & & & $\begin{array}{l}\text { Jasa bandar udara/ } \\
\text { kepelabuhanan } \\
\text { /Port and airport } \\
\text { servives }\end{array}$ & - Tambat labuh /Anchoring \\
\hline & & & $\begin{array}{l}\text { - Jasa lainnya/Other } \\
\text { services }\end{array}$ & $\begin{array}{l}\text { - Listrik /electricity) } \\
\text { - Kebersihan /cleaning) } \\
\text { - Reklame/spanduk /advertising) } \\
\text { - Jasa alat termasuk keranjang, peti } \\
\text { ikan, dll) /Equipment rental, including } \\
\text { tray coolbox, etc } \\
\text { - Pengolahan limbah Maste treatment } \\
\text { - Tangki BBM/air dan instalasinya/ } \\
\text { Mater/fuel tankand its installation } \\
\text { - Alat komunikasi /Communication } \\
\text { facilities }\end{array}$ \\
\hline & & & $\begin{array}{l}\text { - Jasa penjualan } \\
\text { hasil perikanan } \\
\text { (fish and fishery } \\
\text { product sell) }\end{array}$ & $\begin{array}{l}\text { - Ikan /Fish } \\
\text { - Produk hasil perikanan /Fishery } \\
\text { product } \\
\text { - Air, es, BBM Mater,ice dan Fuel }\end{array}$ \\
\hline & & & $\begin{array}{l}\text { - Jasa penjualan } \\
\text { lainnya }\end{array}$ & - Air, es, BBM /Water,ice dan Fuel \\
\hline
\end{tabular}

Sumber: Direktorat Jenderal Perikanan Tangkap (DJPT) - KKP (2009)

Source: General Directorate of Capture Fisheries KKP (2009)

\section{Alokasi Pembiayaan PNBP}

PNBP yang dikumpulkan oleh pelabuhan perikanan dapat dimanfaatkan kembali untuk meningkatkan jasa pelayanan pelabuhan perikanan kepada masyarakat sesuai ketentuan yang berlaku. Beberapa kegiatan yang dapat dibiayai oleh PNBP dapat dilihat pada Tabel 2 .

\section{Permasalahan dalam Peningkatan PNBP}

Berdasarkan hasil pengamatan di pelabuhan perikanan sampel, potensi PNBP yang cukup besar diperoleh dari pungutan perikanan, jasa pelabuhan perikanan, jasa pengujian mutu hasil perikanan dan penyewaan fasilitas. Namun, tidak seluruh potensi PNBP tersebut dapat masuk ke rekening DKP. Hal ini disebabkan karena potensi tersebut ditarik oleh Pemerintah Daerah atau Perusahaan Umum Pasarana Perikanan Samudra (Perum PPS), seperti adanya Perum PPS di PPS Nizam Zachman Jakarta. Jenis pelayanan yang diberikan oleh PPS saat ini melayani jasa pas masuk harian, perbengkelan dan jasa kebersihan. Untuk pelayanan yang bersifat komersial seperti: pelayanan bengkel, tambat labuh, pengadaan es, solar dan air, alat komunikasi dan sewa gudang dikelola oleh Perum PPS. Target dan Realisasi PNBP tahun 2008 pada beberapa pelabuhan perikanan yang diamati dapat dilihat pada Tabel 3. 
Tabel 2. Alokasi Pembiayaan PNBP Untuk Berbagai Kegiatan (Contoh di PPS Nizam Zachman, 2008)

Table 2. Allocation of 'PNBP' for Various Activities (An Example of 'PPS' Nizam Zachman, 2008

\begin{tabular}{|c|c|c|c|c|}
\hline $\begin{array}{c}\text { Kode } \\
\text { MAPI } \\
\text { MAP Code }\end{array}$ & $\begin{array}{c}\text { Program Kegiatan I } \\
\text { Program Activity }\end{array}$ & $\begin{array}{l}\text { Pagu DIPA Rp)/ } \\
\text { Budget (Rp) }\end{array}$ & $\begin{array}{l}\text { Jumlah (Rp)/ } \\
\text { Amount (Rp) }\end{array}$ & $\begin{array}{c}\text { Sisa Dana (Rp)/ } \\
\text { Residual (Rp) }\end{array}$ \\
\hline 5211 & $\begin{array}{l}\text { Belanja barang } \\
\text { operasional/ } \\
\text { Operational spending }\end{array}$ & 230.000 .000 & 158.656 .500 & 71.343 .500 \\
\hline 5212 & $\begin{array}{l}\text { Belanja barang non } \\
\text { operasional /Non - } \\
\text { operational spending }\end{array}$ & 33.600 .000 & 33.600 .000 & \\
\hline 5231 & $\begin{array}{l}\text { Belanja pemeliharaan/ } \\
\text { Maintenance }\end{array}$ & 199.000 .000 & 198.164 .500 & 835.500 \\
\hline 532111 & $\begin{array}{l}\text { Belanja modal } \\
\text { peralatan dan mesin/ } \\
\text { Equipment and } \\
\text { machinary spending }\end{array}$ & 338.500 .000 & 311.240 .000 & 27.260 .000 \\
\hline 524119 & $\begin{array}{l}\text { Belanja perjalanan } \\
\text { lainnya /Trip spending }\end{array}$ & - & - & \\
\hline
\end{tabular}

Sumber: PPSNZJ (2009)/Source: PPSNZJ (2009)

Tabel 3. Target dan Realisasi PNBP pada Pelabuhan Perikanan di Indonesia, 2008

Table 3. Target and Realization of 'PNBP' at Sampled Fishing Port in Indonesia, 2008

\begin{tabular}{|c|c|c|c|c|}
\hline $\begin{array}{l}\text { Nol } \\
\text { No }\end{array}$ & $\begin{array}{l}\text { Pelabuhan Perikanan/ } \\
\text { Fishing Port }\end{array}$ & $\begin{array}{l}\text { Target }(R p) / \\
\text { Target (Rp) }\end{array}$ & $\begin{array}{l}\text { Realisasi (Rp)/ } \\
\text { Realization } \\
\text { (Rp) }\end{array}$ & $\begin{array}{l}\text { Persentase (\%)/ } \\
\text { Percentage (\%) }\end{array}$ \\
\hline 1 & $\begin{array}{l}\text { PPS Nizam Zachman Jakartal } \\
\text { Nizam Zachman Oceanic } \\
\text { Fishing Port }\end{array}$ & 1.060 .000 .000 & 1.143 .182 .252 & 107,85 \\
\hline 2 & $\begin{array}{l}\text { PPS Cilacap / Cilacap } \\
\text { Oceanic Fishing Port }\end{array}$ & 300.000 .000 & 715.777.216 & 238,59 \\
\hline 3 & $\begin{array}{l}\text { PPN Pelabuhan Ratu/ } \\
\text { Pelabuhan Ratu Inter- } \\
\text { island Fishing Port }\end{array}$ & 208.615 .000 & 244.372 .815 & 117,14 \\
\hline 4 & $\begin{array}{l}\text { PPN Pemangkat/ } \\
\text { Pemangkat Inter-island } \\
\text { Fishing Port }\end{array}$ & 35.000 .000 & 19.341 .500 & 55,26 \\
\hline 5 & $\begin{array}{l}\text { PPN Ambon / Ambon } \\
\text { Inter-island Fishing Port }\end{array}$ & 460.000 .000 & 365.083 .810 & 79,37 \\
\hline 6 & $\begin{array}{l}\text { PPP Karangantu Serang/ } \\
\text { Karangantu Fish Landing } \\
\text { Place }\end{array}$ & 129.436 .000 & 30.230 .407 & 23,36 \\
\hline
\end{tabular}

Sumber: Setjen DKP, 2009/Source: Setjen DKP, 2009 
Aset yang dimiliki oleh Perum PPS untuk melaksanakan kegiatannya sebagian besar berasal dari aset yang sebelumnya dikelola oleh pelabuhan perikanan. Sebagai akibat dari adanya pengalihan aset berikut pengelolaannya maka pelabuhan perikanan kehilangan potensi pengumpulan PNBP yang sangat besar.

Hilangnya potensi PNBP Pelabuhan Perikanan yang sangat besar juga terkait dengan adanya kebijakan Menteri Pertanian yang mengatur pemisahan hak dan kewajiban Pelabuhan Perikanan dengan Perum PPS (Keputusan Menteri Pertanian Nomor: 1082/Kpts/OT.210/10/99 tentang Tata Hubungan kerja Unit Pelaksana Teknis Pelabuhan Perikanan dengan Instansi Terkait dalam Pengelolaan Pelabuhan Perikanan). Hingga saat ini Keputusan Menteri Pertanian tersebut masih dijadikan pegangan oleh Perum PPS dalam menyelenggarakan kegiatannya. Penerimaan Perum PPS selama periode tahun 2003-2007 dapat dilihat pada Tabel 4.

Sesuai dengan Peraturan Pemerintah Republik Indonesia Nomor 23 Tahun 2000 tentang Perusahaan Umum Prasarana Perikanan Samudera, Perum PPS adalah Badan Usaha Milik Negara (BUMN) pengelola sarana dan prasarama perikanan, untuk memaksimalkan pemanfaatan sumber daya perikanan yang ada. BUMN tersebut ditugaskan mengusahakan sembilan (9) pelabuhan perikanan sebagai cabang perusahaan dengan kantor pusat di Jakarta. Adapun pelabuhan perikanan yang diusahakan sebagai Cabang Perum PPS adalah : Pelabuhan Perikanan di Muara Baru, Jakarta; Pelabuhan Perikanan di Pekalongan, Jawa Tengah; Pelabuhan Perikanan di Belawan, Sumatera Utara; Pelabuhan Perikanan di Brondong, Jawa Timur; Pelabuhan Perikanan di Lampulo, Nanggroe Aceh Darussalam; Pelabuhan Perikanan di Pemangat, Kalimantan Barat; Pelabuhan Perikanan di Banjarmasin, Kalimantan Selatan; Pelabuhan Perikanan di Tarakan, Kalimantan Timur; dan Pelabuhan Perikanan di Prigi, Jawa Timur.

\section{Strategi Peningkatan PNBP}

Keberadaan pelabuhan perikanan dapat memberikan dampak ganda baik bagi masyarakat maupun Pemerintah Daerah (Susilowati, 2003). Demikian pula halnya dengan peningkatan PNBP di pelabuhan perikanan diharapkan dapat memberikan multiflier effect berupa: peningkatan Pendapatan Asli Daerah (PAD) sebagai dampak tumbuhnya kembangnya kegiatan

Tabel 4. Penerimaan PERUM Prasarana Pelabuhan Perikanan di Indonesia, 2003-2007

Table 4. Revenue of the PERUM Fishing Port Infrastructure in Indonesia, 2003-2007

\begin{tabular}{llrrrrr}
\hline \multirow{2}{*}{$\begin{array}{l}\text { No I } \\
\text { No }\end{array}$} & Lokasi I & \multicolumn{5}{c}{ Nilai Penerimaan, juta rupiah (Revenue, million rupiah) } \\
\cline { 3 - 7 } & Location & \multicolumn{1}{c}{$\mathbf{2 0 0 3}$} & $\mathbf{2 0 0 4}$ & $\mathbf{2 0 0 5}$ & \multicolumn{1}{c}{$\mathbf{2 0 0 6}$} & $\mathbf{2 0 0 7}$ \\
\hline 1 & Jakarta & $44.001,267$ & $57.805,852$ & $71.844,712$ & $78.472,285$ & $65.831,948$ \\
2 & Belawan & $3.713,720$ & $4.051,226$ & $5.282,303$ & $6.054,109$ & $6.156,504$ \\
3 & Prigi & $1.030,239$ & $1.677,701$ & $2.337,909$ & $3.058,296$ & $3.025,876$ \\
4 & Brondong & $10.581,555$ & $16.068,629$ & $24.051,553$ & $23.464,223$ & $10.134,690$ \\
5 & Pekalongan & $1.487,130$ & $1.305,778$ & $1.471,713$ & $1.543,9540$ & $1.300,908$ \\
6 & Pemangkat & 343,182 & $2.385,333$ & $5.500,917$ & $8.122,688$ & $7.519,818$ \\
7 & Lampulo & 111,017 & 64,317 & - & 96,488 & 202,736 \\
\hline & Jumlah/Total & $\mathbf{6 1 . 2 6 8 , 1 1 0}$ & $\mathbf{8 3 . 3 5 8 , 8 3 6}$ & $\mathbf{1 1 0 . 4 8 9 , 1 0 7}$ & $\mathbf{2 0 . 8 1 2 , 0 4 3}$ & $\mathbf{9 4 . 1 7 2 , 4 8 0}$ \\
\hline
\end{tabular}

Sumber : Sekretariat Jenderal (Sekjen) - DKP (2008)

Source: General Secretariate-DKP (2008) 
옹

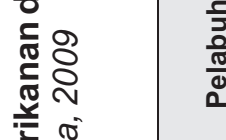

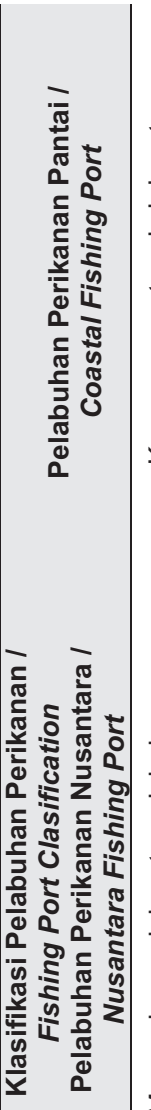

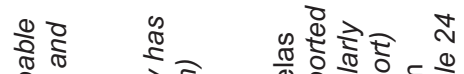

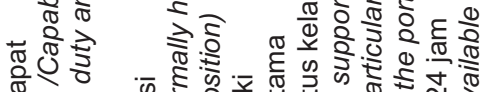

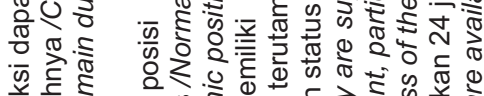

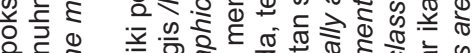

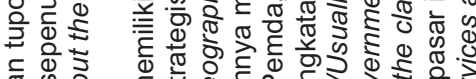

त

ग

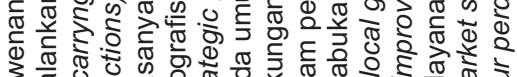

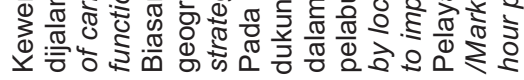

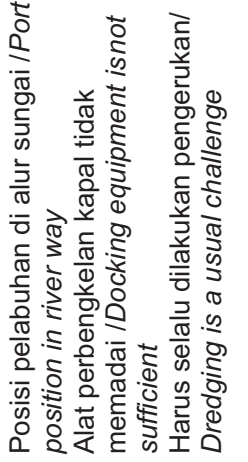

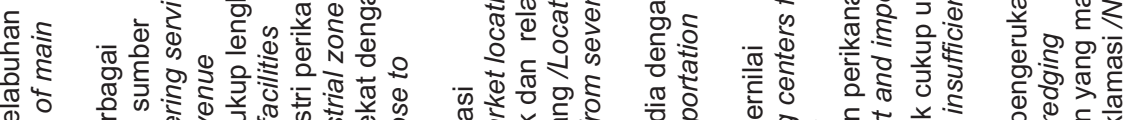

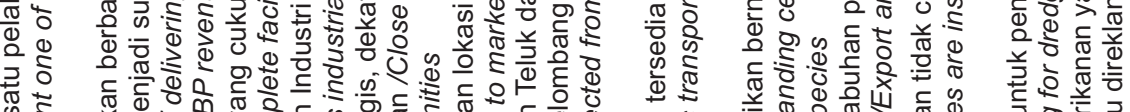

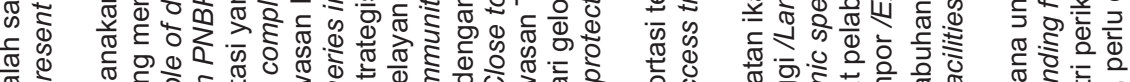

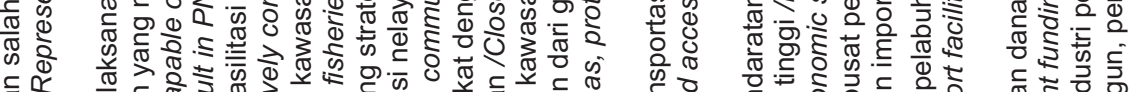

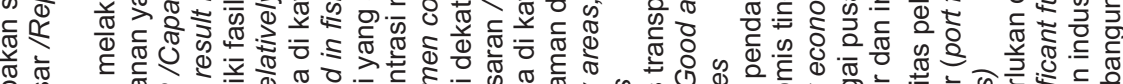

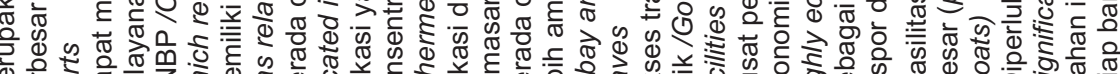

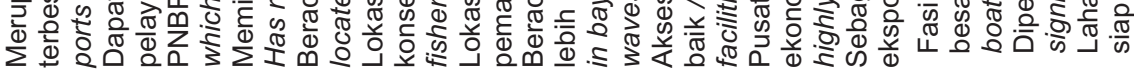

'

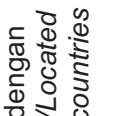

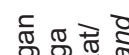

'

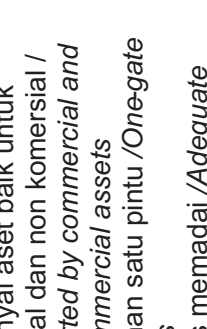

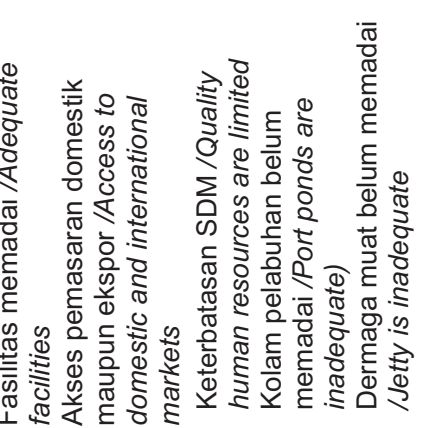

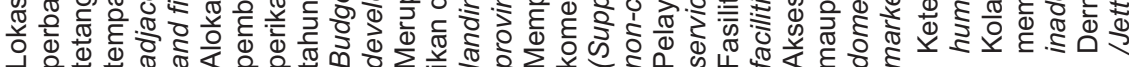




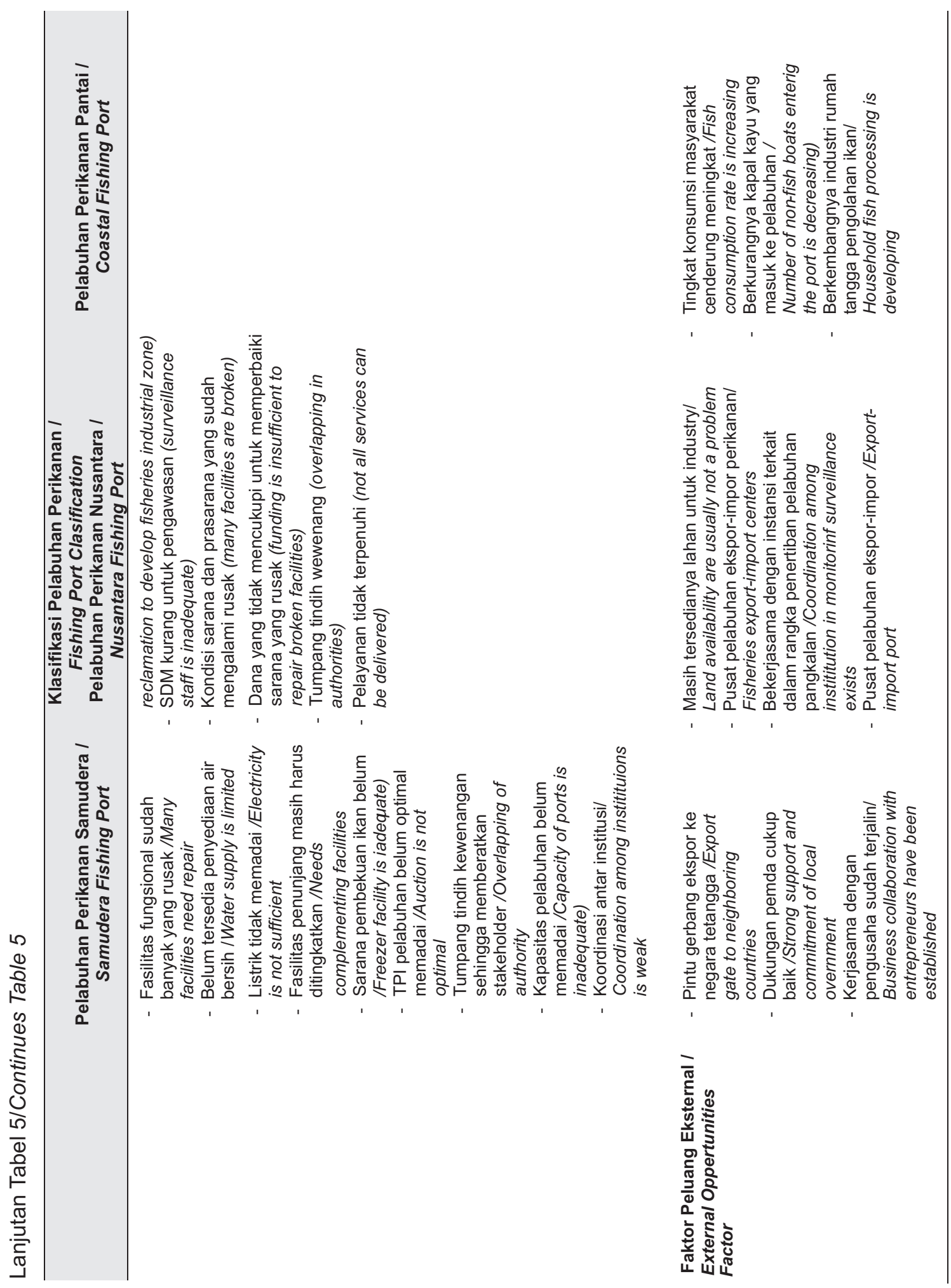




\section{Pelabuhan Perikanan Samudera I Samudera Fishing Port}

\section{Klasifikasi Pelabuhan Perikanan / Fishing Port Clasification \\ Pelabuhan Perikanan Nusantara I Nusantara Fishing Port}

Pelabuhan Perikanan Coastal Fishing
Ancaman

(Threats)
- Kerjasama antar institusi masih lemah /Cooperation among institutions is weak

- Pembebasan lahan masih terkendala /Land acquisition is constrained

- Terjadi tumpang tindih tupoksi dengan istitusi lain, misal PERUM Overlapping with other institutions, e.g., PERUM

- Kualitas SDM nelayan masih rendah /Fishers human resources are low

- Maraknya illegal Fishing/ llegal fishing exists significantly

- Kesadaran nelayan masih rendah untuk melelang ikannya di TPI Auction is ineffective due to low awareness among fishers

- Banyaknya pusat pendaratan ikan pesaing milik swasta /Many competing private landing ports exist

- Masih banyaknya penggunaan pelabuhan oleh kapal pesiar dan kapal komersil lainnya

/The number of commercial and tourist boats is high)
- Kebiasaan masyarakat yang sulit berubah/ Unconducive habit of surrounding communities

- Ada dua peraturan yang digunakan /Two reference regulations exist

- Pengguna jasa yang kurang disiplin dalam membayar kewajibannya / Payment by service users is often untimely

- Tingkat adopsi teknologi masyarakat (technology adoption my communities is low)

- Perbedaan pencatatan yang berbeda antara dinas daerah dengan pelabuhan /Data reporting is often inconsistent)

- Adanya limpasan air laut yang besar (sea water

- Permukaan tanah yang turun /Land surface are descend

- Berkembangnya pesaing yang dapat menyediakan sarana prasarana sejenis/ The expand of competitor can provide similar infrastructure

- Meningkatnya degradasi sumber daya pesisir dan lautan / Coastal and ocean resources degradation are increasing
- Kerusakan alat karenakan k optimalnya penggunaan fasi (malfunction of equipment $d$ improper use)

- Perbedaan pencatatan yang berbeda antara dinas daerah dengan pelabuhan (inconsis data recording among esisti institutions)

- Penggunaan alat tangkap ya dilarang, sehingga nelayan banyak ditangkap karena dic illegal fishing (frequent mista arrest related to illegal fishin

- Nelayan belum mau mendaratkan ikan di pelabur (fishermen's reluctance to la fish at the port)

- Perbedaan persepsi tentang implementasi peraturan (diff perception re. regulations)

- Kapal non-perikanan yang menghambat masuknya kap nelayan ke pelabuhan (congestion due to the prese of non-fish-boat at the ports)

- Banyak nelayan luar daerah yang masuk ke wilayah 


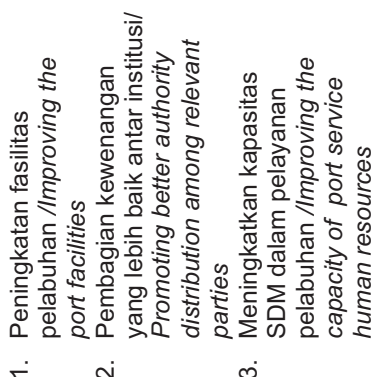

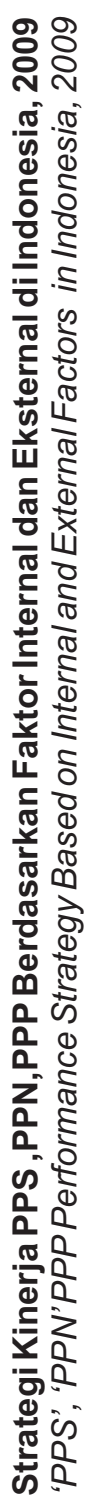

ㅇํㅇำ 赵. \& 흥 홍 등

๘

舫

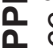

ż

का

0

을

要

क्र

की

ம்

正 $\frac{0}{\frac{0}{6}}$

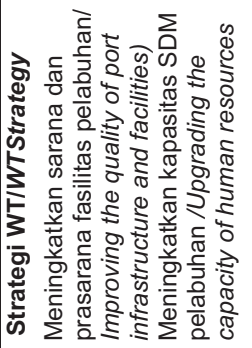

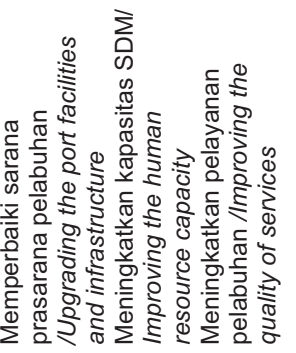
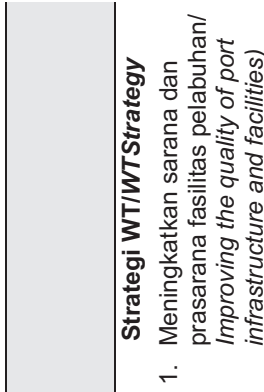

$\frac{\sqrt{2}}{\sqrt[\pi]{\pi}}$

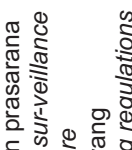

बे क

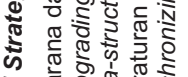

क के के

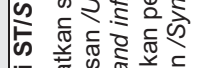

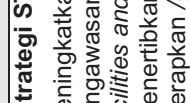

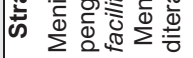

$\therefore \sim$

帝

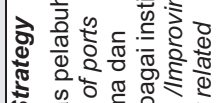

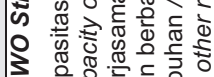

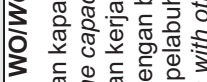

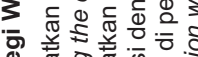

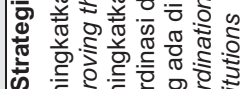

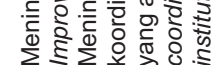

$\therefore$ i

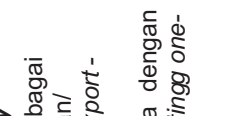

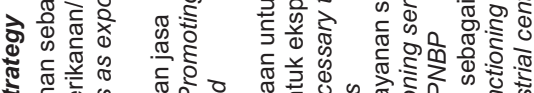

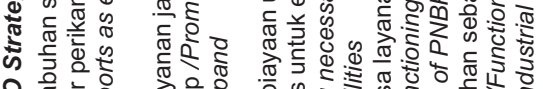

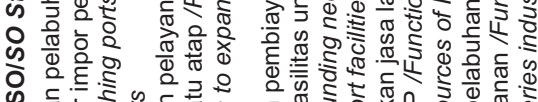

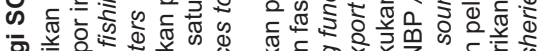

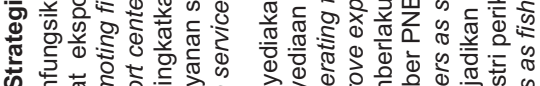

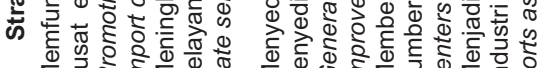

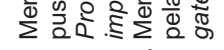

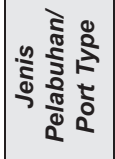

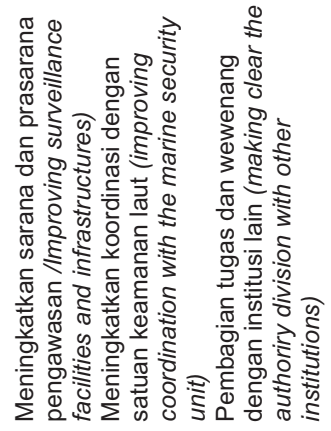

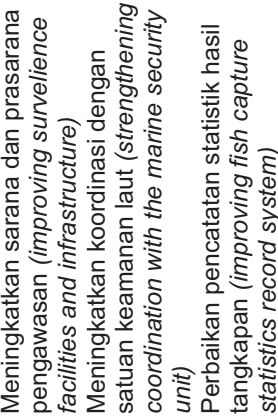

$\therefore$ i

齐

तิ

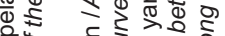

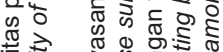

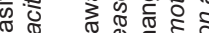

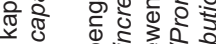

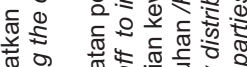

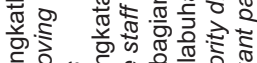

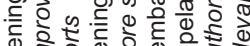

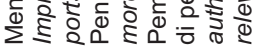

$\therefore$ त

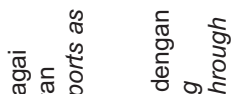

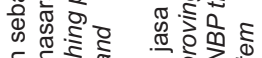

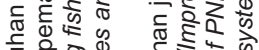

잉

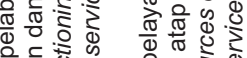

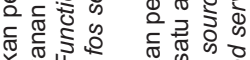

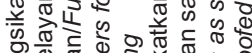

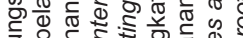

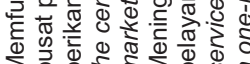

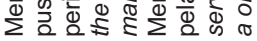

ㄴ

$\frac{0}{0}$ 


\section{Tabel7. Matriks Hasil Analisis SWOT Strategi Kinerja menurut Klasifikasi Pelabuhan Perikanan, 2009}

Table 7. Performance Strategy SWOT Analysis Matrix Acording to Fishing Port Clasification in Indonesia, 2009

\begin{tabular}{|c|c|c|c|}
\hline \multirow[b]{2}{*}{$\begin{array}{l}\text { Nol } \\
\text { No }\end{array}$} & \multicolumn{3}{|c|}{$\begin{array}{l}\text { Klasifikasi Pelabuhan Perikanan / } \\
\text { Fishing Port Clasification }\end{array}$} \\
\hline & $\begin{array}{c}\text { Pelabuhan Perikanan } \\
\text { Samudera / } \\
\text { Samudera Fishing Port }\end{array}$ & $\begin{array}{c}\text { Pelabuhan Perikanan } \\
\text { Nusantara / } \\
\text { Nusantara Fishing Port }\end{array}$ & $\begin{array}{c}\text { Pelabuhan Perikanan } \\
\text { Pantai / } \\
\text { Coastal Fishing Port }\end{array}$ \\
\hline 1 & $\begin{array}{l}\text { Memfungsikan pelabuhan } \\
\text { sebagai pusat ekspor } \\
\text { impor perikanan/ } \\
\text { Promoting fishing ports } \\
\text { as export-import centers }\end{array}$ & $\begin{array}{l}\text { Adanya pembagian } \\
\text { kewenangan antara } \\
\text { berbagai pihak terkait di } \\
\text { pelabuhan /Distributing } \\
\text { authority among relevant } \\
\text { parties) }\end{array}$ & $\begin{array}{l}\text { Memfungsikan pelabuhan } \\
\text { sebagai pusat pelayanan } \\
\text { dan pemasaran perikanan/ } \\
\text { Functioning fishing ports } \\
\text { as the centers for } \\
\text { services and marketing }\end{array}$ \\
\hline 2 & $\begin{array}{l}\text { Meningkatkan kapasitas } \\
\text { pelabuhan di beberapa } \\
\text { lokasi supaya dapat } \\
\text { menampung lebih banyak } \\
\text { kapal berlabuh /Improving } \\
\text { the capacity of ports to } \\
\text { accommodate more } \\
\text { boats }\end{array}$ & $\begin{array}{l}\text { Menyediakan } \\
\text { pembiayaan untuk } \\
\text { penyediaan fasilitas } \\
\text { pelabuhan terutama untuk } \\
\text { ekspor ikan /Generating } \\
\text { funding necessary to } \\
\text { improve export facilities) }\end{array}$ & $\begin{array}{l}\text { Meningkatkan kapasitas } \\
\text { pelabuhan di beberapa } \\
\text { lokasi supaya dapat } \\
\text { menampung lebih banyak } \\
\text { kapal berlabuh /Improving } \\
\text { the capacity of the ports } \\
\text { to accommodate more } \\
\text { boats }\end{array}$ \\
\hline 3 & $\begin{array}{l}\text { Meningkatkan sarana dan } \\
\text { prasarana pengawasan/ } \\
\text { Upgrading surveillance } \\
\text { facilities andinfrastructure }\end{array}$ & $\begin{array}{l}\text { Penyediaan SDM yang } \\
\text { memadai untuk } \\
\text { operasional lebih baik/ } \\
\text { Providing better human } \\
\text { resources for better } \\
\text { operational }\end{array}$ & $\begin{array}{l}\text { Peningkatan fasilitas } \\
\text { pelabuhan /Improving the } \\
\text { port facilities }\end{array}$ \\
\hline 4 & $\begin{array}{l}\text { Meningkatkan sarana dan } \\
\text { prasarana fasilitas } \\
\text { pelabuhan /Improving the } \\
\text { quality of port } \\
\text { infrastructure and } \\
\text { facilities }\end{array}$ & $\begin{array}{l}\text { Pembagian tugas dan } \\
\text { wewenang yang jelas } \\
\text { dengan institusi lain/ } \\
\text { Making clear the } \\
\text { authority division with } \\
\text { other institutions) }\end{array}$ & $\begin{array}{l}\text { Meningkatkan pelayanan } \\
\text { jasa sebagai sumber } \\
\text { PNBP dengan pelayanan } \\
\text { satu atap /Improving } \\
\text { services as sources of } \\
\text { PNBP through a one- } \\
\text { roofed service system) }\end{array}$ \\
\hline 5 & $\begin{array}{l}\text { Meningkatkan pelayanan } \\
\text { jasa sebagai sumber } \\
\text { PNBP dengan pelayanan } \\
\text { satu atap /Promoting } \\
\text { one-gate services to } \\
\text { expand sources of PNBP }\end{array}$ & $\begin{array}{l}\text { Menjadikan pelabuhan } \\
\text { sebagai pusat industri } \\
\text { perikanan /Functioning } \\
\text { fishing ports as fisheries } \\
\text { industrial center }\end{array}$ & $\begin{array}{l}\text { Meningkatkan koordinasi } \\
\text { dengan satuan keamanan } \\
\text { laut /Strengthening } \\
\text { coordination with the } \\
\text { marine security unit }\end{array}$ \\
\hline
\end{tabular}


perikanan di daerah melalui pembangunan pelabuhan perikanan; penyerapan tenaga kerja non nelayan yang beraktivitas di pelabuhan perikanan; dan ekonomi daerah bergairah terutama sektor jasa yang terkait dengan kegiatan pelabuhan perikanan.

Berdasarkan pengamatan yang dilakukan di PPS Nizam Zachman Jakarta, PPS Cilacap, PPN Pelabuhan Ratu, PPN Ambon, PPN Pemangkat dan PPP Karangantu Serang, hasil pengamatan dapat dikelompokkan ke dalam tiga kelompok berdasarkan klasifikasi pelabuhan yang dikunjungi (PPS, PPN dan PPP). Hal ini disebabkan setiap pelabuhan tersebut mempunyai karakteristik, tugas dan fungsi yang berbeda, sehingga diharapkan strategi untuk memperbaiki kinerja dan optimalisasi PNBP dari setiap tipe pelabuhan tersebut akan berbeda sesuai dengan kondisi dan permasalahan yang ada. Analisis SWOT dilakukan berdasarkan tipe pelabuhan terhadap faktor internal dan faktor eksternal untuk setiap jenis pelabuhan perikanan. Analisis faktor internal mencakup faktor kekuatan dan kelemahan, sedangkan analisis eksternal mencakup faktor peluang dan ancaman. Secara rinci hasil analisisnya dapat dilihat pada Tabel 5.

Berdasarkan hasil identifikasi terhadap faktor-faktor internal yaitu kekuatan dan kelemahan, serta faktor-faktor eksternal yaitu peluang dan ancaman terhadap kinerja pelabuhan perikanan, maka diformulasikan strategi pada matriks SWOT erdasarkan lima (5) faktor prioritas. Strategi tersebut adalah: (i) Strategi SO yang diformulasikan dengan menggunakan kekuatan untuk memanfaatkan peluang; (ii) Strategi ST yang diformulasikan dengan menggunakan kekuatan untuk mengatasi ancaman; (iii) Strategi WO yang diformulasikan dengan meminimalkan kelemahan untuk memanfaatkan peluang; dan (iv) Strategi WT yang diformulasikan dengan mengendalikan kelemahan untuk menghindari ancaman. Secara lengkap strategi matriks SWOT dapat dilihat pada Tabel 6.
Berdasarkan faktor-faktor strategis kinerja untuk setiap klasifikasi pelabuhan perikanan dilakukan analisis terhadap masingmasing matriks SWOT untuk menggambarkan relasi diantara faktor-faktor yang ada. Hubungan tersebut menghasilkan strategi kinerja yang dikelompokkan ke dalam empat (4) strategi utama, yaitu strategi SO, strategi ST, strategi WO dan strategi WT pada PPS, PPN dan PPP. Strategi tersebut selanjutnya dibobotkan sehingga diperoleh hasil penilaian bobot untuk masing-masing faktor tersebut, dapat ditentukan strategi yang mempengaruhi kinerja menurut klasifikasi pelabuhan (Tabel 7).

Secara garis besar strategi yang dapat ditentukan dalam mempengaruhi peningkatan kapasitas pelabuhan perikanan dalam optimalisasi PNBP adalah sebagai berikut: (a) memfungsikan pelabuhan sebagai pusat ekspor impor perikanan; (b) memaksimalkan kualitas jasa berdasarkan sarana dan prasarana saat ini; (c) perbaikan dan penambahan sarana-prasarana pelabuhan; (d) peningkatan kapasitas sumber daya manusia; (e) meningkatkan kerjasama dengan institusi terkait; dan (f) peningkatan pengawasan serta perbaikan aturan dan implementasinya.

\section{KESIMPULAN DAN IMPLIKASI KEBIJAKAN}

\section{Kesimpulan}

Kesimpulan yang dapat diberikan dari penelitian ini adalah:

1. Secara umum potensi PNBP cukup besar diperoleh dari pungutan perikanan, jasa pelabuhan perikanan, jasa pengujian mutu hasil perikanan dan penyewaan fasilitas, namun tidak seluruh potensi PNBP tersebut dapat masuk ke rekening DKP.

2. Strategi untuk meningkatkan PNBP dapat dikaitkan dengan upaya meningkatkan jenis dan kualitas jasa layanan pelabuhan sebagai berikut: (a) memaksimalkan kualitas layanan jasa dengan sarana 
prasarana yang ada; (b) perbaikan dan penambahan sarana-prasarana pelabuhan; (c) peningkatan kapasitas sumberdaya manusia; (d) meningkatkan kerjasama dengan institusi terkait; dan (e) peningkatan pengawasan serta perbaikan aturan serta implementasinya

3. Peningkatan jasa layanan sebaiknya mendapatkan perhatian yang lebih serius, disebabkan dengan meningkatnya layanan yang diberikan lebih baik dapat meningkatkan penghasilan negara meningkat.

\section{Implikasi Kebijakan}

Implikasi dari hasil ini adalah pentingnya upaya meningkatkan pelayanan pelabuhan perikanan untuk meningkatkan PNBP sektor kelautan dan perikanan. Beberapa kegiatan yang harus dilakukan untuk meningkatkan kinerja pelabuhan akan berimplikasi pada pembiayaan anggaran khususnya untuk peningkatan layanan karena harus dilaksanakan melalui perbaikan sarana dan prasarana. Dalam jangka panjang peningkatan pelayanan tersebut akan meningkatkan PNBP dari layanan yang diberikan dari pelabuhan tersebut.

\section{DAFTAR PUSTAKA}

Annonimous. 2009. Laporan Tahunan 2008 Pelabuhan Perikanan Samudera Nizam Zachman Jakarta. PPSNZJ Direktorat Jenderal Perikanan Tangkap DKP, Jakarta

2009 . Target dan Realisasi Penerimaan Negara Bukan Pajak Departemen Kelautan dan Perikanan. Sekretariat Jenderal DKP, Jakarta. 2009. Undang-Undang Republik Indonesia Nomor 45 Tahun 2009 tentang Perubahan Atas UndangUndang Nomor 31 Tahun 2004 tentang Perikanan. Departemen Kelautan dan Perikanan. Jakarta.
2002. Peraturan Pemerintah Republik Indonesia Nomor 62 Tahun 2002 tentang Tarif Atas Jenis Penerimaan Negara Bukan Pajak yang Berlaku pada Departemen Kelautan dan Perikanan. Jakarta. 2000. Peraturan Pemerintah Republik Indonesia Nomor 23 Tahun 2000 tentang Perusahaan Umum (PERUM) Prasarana Perikanan Samudera. Jakarta. 1997. UU No. 20 Tahun 1997 tentang Penerimaan Negara Bukan Pajak.

Lubis, E. 2000. Pengantar Pelabuhan Perikanan (Buku I). Laboratorium Pelabuhan Perikanan Jurusan PSP. Fakultas Perikanan dan IImu Kelautan IPB, Bogor.

Nasir M. 1983. Metode Penelitian. Ghalia Indonesia, Jakarta.

Rangkuti F. 2002. Analisis SWOT: Teknik Membedah Kasus Bisnis. Reorientasi Konsep Perencanaan Strategis untuk Menghadapi Abad 21. PT Gramedia Pustaka Utama, Jakarta.

Susilowati, B. 2003. Analisis Peran Pelabuhan Perikanan dan Hubungannya dengan Kesejahteraan Masyarakat (Studi Kasus di Pelabuhan Perikanan Samudera Jakarta keluaran Penjaringan Jakarta). Tesis Pascasarjana IPB. Bogor.

Wheelen, T.L. and J.D. Hunger. 2000. Strategic Management Business Policy, Concept and Cases. $8^{\text {th }}$ Edition. Upper Saddle River. New Jersey. 